\title{
Analisis Atas Annual Report PT Timah Tbk: Studi Interpretive Dalam Perspektif Semiotika dan Retorika
}

\author{
Oktaviani* \\ Universitas Tanjungpura \\ Rusliyawati \\ Universitas Tanjungpura \\ Elok Heniwati \\ Universitas Tanjungpura
}

\begin{abstract}
The purpose of this study is to analyze and understand about the integrated annual report (integrated report) of PT Timah Tbk by answering research question about how is the rhetorical aspect and semiotic aspects, that is the aspect of semantic, syntactic, and pragmatic. Interpretive paradigm and semiotic approach is used to analyze the integrated annual report. The data used is integrated annual report of PT Timah Tbk in 2013, 2014 and 2015. This study showed that the semiotic aspects was poured into the points of reporting in the integrated annual report of the company. The integrated annual report of PT Timah Tbk was created by the company as a rhetorical story to build a positive image and to gain legitimacy from its stakeholders.
\end{abstract}

Keywords: rhetoric, integrated reporting, semantic, syntactic, pragmatic

\section{PENDAHULUAN}

Seiring dengan perkembangan bisnis dan teknologi, tuntutan informasi dalam rangka untuk pengambilan keputusan membuat ruang lingkup di dalam pelaporan keuangan semakin berkembang. Perkembangan tersebut menuju kearah sebuah model pelaporan baru yang disebut dengan integrated reporting atau annual report yang telah terintegrasi. Integrated Reporting (IR) didefinisikan sebagai suatu proses komunikasi informasi suatu organisasi yang tercermin dalam integrated report kepada para stakeholders tentang penciptaan nilai dari waktu ke waktu (IIRC, 2013). Itu berarti

\footnotetext{
* Korespondensi: Oktaviani, Alumna Jurusan Akuntansi, Fakultas Ekonomi dan Bisnis, Universitas Tanjungpura, Jalan Prof. DR. H. Hadari Nawawi, Pontianak 78124, Indonesia. Email: oktachan88@gmail.com
} 
integrated reporting merupakan sarana komunikasi informasi bagi pihak yang berkepentingan. Sehingga pelaporan keuangan dikatakan sebagai sebuah bahasa bisnis.

Jika berbicara mengenai komunikasi, tidak dapat terlepas dari bahasa. Begitu pula dengan pelaporan keuangan pada annual report yang di dalamnya terdapat narrative text. Narrative text yang terdapat di dalam annual report mengandung aspek semiotik. Semiotika adalah bidang kajian yang membahas teori umum tentang tandatanda (signs) dan simbol-simbol dalam bidang linguistika (Suwardjono, 2005). Semiotika itu sendiri terbagi menjadi tiga tataran yaitu semantik, sintaktik dan pragmatik.

Segala informasi yang terkandung di dalamnya, tentu memiliki makna dan pesan serta maksud tersendiri. Manajemen perusahaan harus dapat membuat teks naratif yang memiliki makna yang sesuai dengan pesan yang ingin disampaikan perusahaan kepada para stakeholders. Maka proses inilah yang disebut dengan retorika. Pentingnya pemahaman atas narrative text, tanda, simbol dan makna dari suatu kalimat inilah yang disebut dengan retorika.

Terdapat beberapa penelitian terdahulu yang melakukan penelitian dari sisi semiotik salah satunya adalah Martono (2016) yang meneliti tentang evolusi dalam pelaporan keuangan pada integrated report perusahaan, yang pembahasannya dilakukan sesuai dengan tiga tataran pada aspek semiotika. Penelitian sejenis juga dilakukan oleh Nugroho (2009) yang meneliti terkait retorika pada sustainability report perusahaan dengan menggunakan analisis semiotik namun pembahasannya tidak menggunakan tiga tataran pada aspek semiotika.

Atas dasar uraian latar belakang di atas serta berdasarkan beberapa penelitian yang telah dilakukan sebelumnya maka penilitian ini dibangun atas dasar bahwa pelaporan keuangan yang dilakukan perusahaan melalui annual report yang telah terintegrasi (integrated report) adalah sebuah sarana komunikasi yang digunakan perusahaan untuk menyediakan dan menyampaikan informasi-informasi penting yang dapat digunakan untuk membentuk cerita retorik (rhetorical story) terkait kinerja perusahaan tersebut. Apapun yang terjadi, perusahaan harus dapat mempertahankan kelangsungan hidupnya dari tuntutan para pemangku kepentingan. Pentingnya pelaporan keuangan sebagai sarana komunikasi, retorika yang dibentuk oleh manajemen perusahaan tidak dapat dilakukan dengan pendekatan kuantitatif dan tidak dapat dipisahkan dari aspek semiotik. Hal ini dikarenakan aspek semiotik inilah yang membentuk bahasa yang digunakan dalam komunikasi.

Nilai kebaruan atau perbedaan dari penelitian ini dengan penelitian yang sebelumnya terletak pada pembahasan retorika yang dilakukan pada model pelaporan baru, yang disebut integrated reporting, dengan menggunakan analisis semiotik yang pembahasannya menggunakan tiga tataran pada aspek semiotika. Selain itu nilai kebaruan juga terletak pada objek penelitian yaitu PT Timah Tbk. 
Adapun tujuan dilakukannya penelitian ini adalah untuk melakukan pemahaman dan analisis terhadap aspek semiotika yang terdiri dari aspek semantik, sintaktik, dan pragmatik yang terkandung di dalam annual report PT Timah Tbk serta untuk melakukan pemahaman dan analisis atas cerita retorik di dalam bagian-bagian pelaporan pada annual report PT Timah Tbk

Dikarenakan belum adanya penelitian yang meneliti tentang retorika pada model pelaporan baru yang disebut integrated reporting, serta pentingnya pemahaman atas makna pada narrative text yang terdapat pada pelaporan yang dilakukan oleh perusahaan, maka peneliti tertarik untuk melakukan penelitian ini. Selain itu, hasil dari penelitian ini juga akan memberikan pemahaman yang lebih menyeluruh kepada para stakeholders terkait informasi yang disajikan oleh perusahaan. Hal ini dikarenakan pembahasan pada penelitian ini dilakukan dengan lebih lengkap dan terinci melalui aspek semiotika dan retorika, sehingga para stakeholders dapat lebih mudah memahami informasi yang disampaikan oleh perusahaan.

\section{LITERATURE REVIEW}

\subsection{Retorika Dalam Pelaporan Keuangan Perusahaan}

Menurut Oxford English Dictionary (1989) di dalam Brennan \& Gray (2000) mendefinisikan retorika sebagai seni menggunakan bahasa untuk membujuk/ mengajak/meyakinkan atau mempengaruhi orang lain yang dinyatakan secara langsung seperti pidato maupun dalam bentuk tulisan dalam hubungan diperhitungkan untuk membujuk atau mengesankan orang lain (sering kali dalam pengertian menjatuhkan atau menurunkan).

Dalam pengertian tersebut dapat disimpulkan bahwa retorika mengacu pada bahasa yang dimaksudkan untuk meyakinkan atau membujuk seseorang untuk merasa, berpikir, atau melakukan sesuatu untuk sebuah alasan yang nyata ketika alasan yang sebenarnya itu berbeda. Menurut Covaleski, Dirsmith \& Samuel (1995) di dalam Brennan \& Gray (2000) memberikan komentar bahwa akuntansi bukan hanya merupakan sebuah alat untuk mewakili realitas ekonomi tetapi juga merupakan sebuah perangkat retoris untuk pengaturan dan sebagainya.

\subsection{Aspek Semiotik Dalam Pelaporan Keuangan Sebagai Bahasa Bisnis}

Dalam teori komunikasi, semiotik menjadi salah satu kajian yang menjadi tradisi. Tradisi semiotik terdiri atas sekumpulan teori tentang bagaimana tanda-tanda merepresentasikan benda, ide, keadaan, situasi, perasaan dan kondisi di luar tanda-tanda itu sendiri (Littlejohn, 2009:53). Semiotik mempelajari sistem-sistem, aturan-aturan, konvensi-konvensi yang memungkinkan tanda-tanda tersebut mempunyai arti (Kriyantono, 2007:261). Suwardjono (2005) mengartikan semiotika sebagai suatu bidang 
kajian yang membahas teori umum tentang tanda-tanda (signs) dan simbol-simbol dalam bidang linguistika.

Sebagai teori umum dalam penyimbolan informasi, Suwardjono (2005) menyatakan semiotika membahas tiga pertanyaan pokok yang berkaitan dengan simbol informasi. Ketiga pertanyaan tersebut, antara lain apakah simbol tersebut logis atau masuk akal? Apa makna yang terkandung di dalam simbol? Dan apakah ungkapan tersebut mempunyai efek atau pengaruh terhadap penerima? Dari pernyataan diatas maka terbentuklah tiga tataran semiotika yaitu sintatika, semantika, dan pragmatika.

Pada teori akuntansi semantik, penekanan dilakukan pada pembahasan masalah penyimbolan dunia nyata atau realitas (kegiatan perusahaan) ke dalam tanda-tanda bahasa akuntansi (elemen laporan keuangan) sehingga orang dapat membayangkan kegiatan fisis yang dilakukan perusahaan tanpa harus menyaksikan secara langsung kegiatan tersebut.

Teori akuntansi sintaktik merupakan teori yang berorientasi untuk membahas masalah-masalah yang terkait dengan bagaimana kegiatan-kegiatan perusahaan yang telah disimbolkan secara semantik dalam bentuk elemen-elemen keuangan dapat diwujudkan dalam bentuk statemen keuangan. Simbol yang dimaksud adalah seperti aset, utang, pendapatan dan lainnya. Pada teori akuntansi pragmatik, fokus pembahasan terpusat pada pengaruh informasi terhadap perubahan perilaku pada pemakai laporan. Dengan kata lain, teori ini membahas mengenai reaksi yang muncul dari pihak yang dituju informasi akuntansi.

\subsection{Integrated Reporting : Sebuah Cerita Retoris dan Semiotika}

Terkait dengan pelaporan, model pelaporan baru muncul dan dikembangkan oleh The International Integrated Reporting Council's (IIRC) dengan dukungan dari Global Reporting Initiatives (GRI). Model pelaporan baru tersebut dinamakan Integrated Reporting. Integrated Reporting ini dibangun diatas model pelaporan keuangan yang ada untuk menggabungkan informasi non-keuangan yang dapat membantu para pemangku kepentingan memahami bagaimana sebuah perusahaan menciptakan dan menopang nilai lebih dari waktu jangka panjang.

Integrated Reporting memiliki prinsip-prinsip dan elemen-elemen sesuai dengan kerangka penyajian yang diterbitkan oleh IIRC. Prinsip-prinsip tersebut adalah Fokus Strategi dan Orientasi Masa Depan, Konektivitas Informasi, Hubungan Dengan Stakeholder, Materialitas, Keringkasan, Keandalan dan Kelengkapan, Konsisten dan Keterbandingan.

Sedangkan elemen-elemen pada integrated reporting terdiri dari Ikhtisar Organisasi dan Lingkungan Eksternal, Tata Kelola, Model Bisnis, Risiko dan Peluang, 
Strategi dan Alokasi Sumberdaya, Kinerja, Pandangan Masa Depan, Basis Penyusunan dan Penyajian.

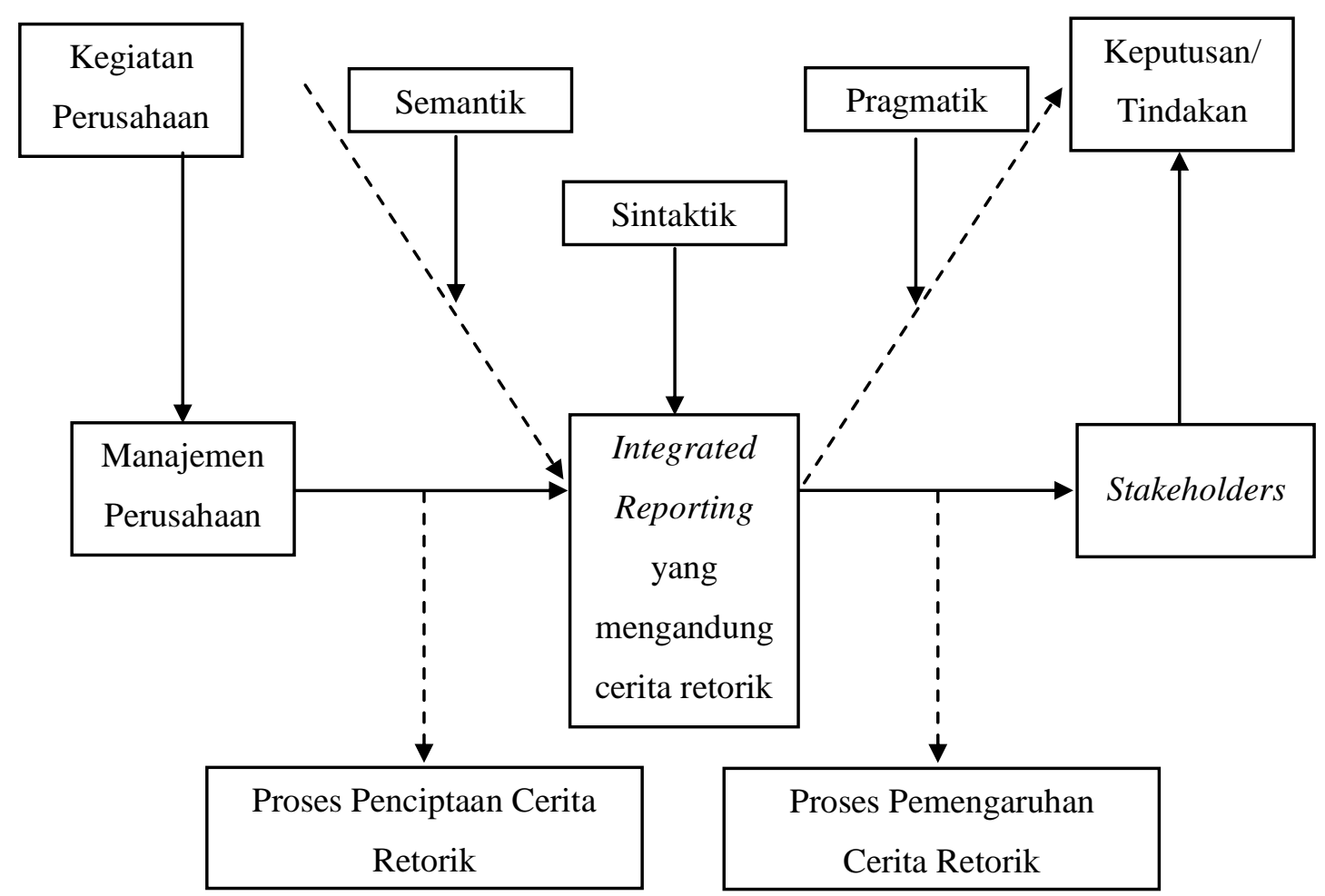

Sumber : Dimodifikasi dari Suwardjono (2005)

Gambar 1. Kerangka Konseptual

Pelaporan keuangan perusahaan yang dibuat berdasarkan aktivitas-aktivitas yang terjadi di perusahaan sering disertai dengan adanya informasi tambahan yang bertujuan untuk mempengaruhi serta meyakinkan para penggunanya. Sehingga dapat ditarik kesimpulan bahwa pihak yang dituju oleh informasi tersebut adalah stakeholders. Pelaporan keuangan dibuat dengan sedemikian rupa sehingga diharapkan dapat memberikan efek komunikasi yang positif, yaitu agar pihak yang dituju informasi yakni stakeholders dapat menanamkan modal atau dananya ke kegiatan ekonomik yang dibutuhkan masyarakat melalui perusahaan tersebut. Selain itu perusahaan juga berharap bahwa pelaporan tersebut juga dapat memberikan kesan yang baik sehingga citra positif perusahaan dapat terbentuk.

Pesan dan harapan tersembunyi tersebut ingin disampaikan oleh perusahaan kepada para stakeholders sebagai masukan maupun dasar pertimbangan mereka di dalam melakukan suatu tindakan pengambilan keputusan. Integrated reporting yang mengandung cerita retorik merupakan media penyampaian pesan tersebut. 


\section{METODA PENELITIAN}

Pendekatan dan pemilihan jenis penelitian pada penelitian ini diawali dengan menempatkan bidang penelitian ke dalam jenis penelitian kualitatif yang berdasarkan pada paradigma interpretif yang bertujuan untuk menafsirkan dan memahami serta memberikan pedoman atas pemilihan pendekatan penelitian yang tepat yaitu semiotik. Pendekatan semiotik digunakan dengan merujuk pada penelitian Nugroho (2009) dan Martono (2016).

Menurut Schaltzman \& Strauss (1973) dalam Moleong (2006) terdapat tiga tujuan penafsiran data, yakni deskripsi semata-mata, deskripsi analitik, dan teori substantif. Pada penelitian ini penafsiran data bertujuan untuk deskripsi semata-mata terhadap penerapan integrated reporting yang akan diklasifikasi melalui tiga tataran semiotika serta deskripsi mengenai cerita retorik yang dibuat oleh perusahaan melalui narrative text.

Penelitian ini menggunakan dua unit analisis, yang pertama terkait dengan tiga tataran pada aspek semiotika yaitu dilakukan dengan cara menginterpretasikan dan mendeskripsikan secara rinci penerapan integrated reporting yang dilakukan oleh perusahaan melalui pengidentifikasian kata, kalimat, gambar maupun simbol pada narrative text yang terdapat disetiap poin utama dalam integrated report perusahaan dengan memperhatikan kesesuaian penerapan dengan prinsip-prinsip maupun elemenelemen pada IIRC. Kesesuaian penyajian yang dilakukan oleh perusahaan dengan prinsip dan elemen tersebut dilakukan dengan cara mencocokkan informasi dari hasil penyajian dengan teori prinsip dan elemen pada IIRC. Setiap poin dapat dikategorikan sebagai prinsip maupun elemen, tergantung kecocokkan informasi yang tersaji dengan prinsipprinsip dan elemen-elemen tersebut.

Unit analisis yang kedua terkait dengan aspek retorika. Yang dilaksanakan dengan cara menginterpretasikan dan mendeskripsikan cerita retorik yang terdapat di dalam annual report yang telah terintegrasi atau integrated report. Proses ini dilakukan dengan cara menganalisis penggunaan kata maupun kalimat yang dikategorikan sebagai cerita retoris pada setiap poin yang telah dibahas. Kata maupun kalimat dikategorikan sebagai cerita retoris berdasarkan teori retorika itu sendiri.

Jenis data yang digunakan dalam penelitian ini adalah jenis data sekunder. Data sekunder yang digunakan berupa annual report PT Timah Tbk yang diperoleh dari situs resmi PT Timah Tbk. Annual report yang digunakan adalah annual report yang telah terintegrasi atau yang sering disebut dengan integrated report. Penggunaan integrated reporting sebagai model pelaporan didalam penelitian ini merujuk pada penelitian Martono (2016). Adapun integrated report yang dianalisis adalah integrated report tahun 2013, 2014 dan 2015. Data penelitian ini dikumpulkan dengan menggunakan metode dokumenter. 
Sudut pandang penelitian ini adalah berdasarkan perusahaan yang diteliti. Peneliti akan menginterpretasikan data dari sudut pandang perusahaan yang telah dituangkan ke dalam integrated report. Objek di dalam penelitian ini adalah salah satu Badan Usaha Milik Negara (BUMN) yang bergerak di bidang pertambangan timah yaitu PT Timah Tbk.

\section{PEMBAHASAN}

\subsection{Aspek Semantik dan Sintaktik Dalam Integrated Reporting PT Timah}

Proses semantik tidak lain merupakan memilih dan menyimbolkan objek-objek fisis kegiatan perusahaan yang relevan menjadi objek-objek yang disebut sebagai elemen-elemen statemen keuangan. Untuk menyimbolkan kegiatan-kegiatan yang telah disimbolkan secara semantik dalam elemen-elemen keuangan, secara sintaktik PT Timah mewujudkannya dalam bentuk statemen keuangan dengan menggunakan format integrated reporting. Aspek semantik dan sintaktik dituangkan oleh perusahaan dalam poin-poin pelaporan dalam annual report yang telah terintegrasi atau integrated annual report milik PT Timah. Berikut pembahasan lebih lanjut mengenai aspek semantik dan sintaktik dari integrated report PT Timah untuk periode tahun 2013, 2014, dan 2015.

Pada integrated annual report tahun 2013 terdiri dari 420 halaman dan terdapat 9 poin utama yang dilaporkan. Tahun 2014 terdiri dari 452 halaman dan 11 poin utama. Sedangkan pada tahun 2014 terdiri dari 475 halaman dan 12 poin utama. Pembahasan untuk ketiga periode dan seluruh poin akan dikelompokkan menjadi satu sesuai dengan jenis informasi yang tercantum.

Pembahasan pada poin pertama terkait dengan Tampilan Sampul (Cover) Depan. Untuk tahun 2013, pada sampul menampilkan 35 buah foto yang digabung menjadi satu foto. Terdapat foto para karyawan PT Timah, foto anak-anak (dalam konteks masyarakat), foto hewan serta foto lingkungan. Pada sampul juga tertulis sebuah tulisan "Maju Bersama Perubahan Menuju Kejayaan". Sesuai dengan tulisan tersebut dapat dilihat bahwa perusahaan ingin maju bersama dengan lingkungan dan sosialnya untuk melakukan perubahan demi menuju kesuksesan pada masa yang akan datang. Aspek semantik tersebut menunjukkan bahwa perusahaan menerapkan prinsip yang diterbitkan oleh IIRC yaitu fokus strategi dan orientasi masa depan.

Berbeda dengan sampul pada tahun sebelumnya, pada tahun 2014 perusahaan tidak menggunakan tampilan beberapa foto pada sampulnya melainkan hanya menampilkan pemandangan sederhana yaitu laut disertai dengan pasir dan langit cerah serta matahari yang bersinar. Pada sampul tersebut tertulis "Efisiensi dan Pertumbuhan Berkesinambungan". Dari tampilan serta tulisan pada sampul, perusahaan ingin menunjukkan bahwa perusahaan ingin berfokus pada efisiensi pada segala aspek yang dilakukan perusahaan serta tetap terus berfokus pada pertumbuhan lingkungan dan aspek lainnya secara terus-menerus. 
Tabel 4.1 Lokasi Aspek Semantik dan Sintaktik pada Integrated Reporting

\begin{tabular}{|c|c|c|c|c|c|}
\hline \multicolumn{6}{|c|}{ Aspek Semiotika } \\
\hline \multicolumn{6}{|c|}{ Aspek Semantik dan Sintaktik } \\
\hline No & $\begin{array}{c}\text { Poin Pembahasan pada } \\
\text { Integrated Report }\end{array}$ & $\begin{array}{l}\text { Prinsip-prins } \\
\text { Integrated } R\end{array}$ & & $\begin{array}{l}\text { Elemen-elemen } \mathrm{Pc} \\
\text { Integrated Report }\end{array}$ & \\
\hline 1 & Tampilan Sampul (Cover) & $\begin{array}{l}\text { Fokus Strategi } \\
\text { dan Orientasi } \\
\text { Masa Depan }\end{array}$ & $\sqrt{ }$ & - & - \\
\hline 2 & Tentang Laporan Ini & $\begin{array}{l}\text {-Materialitas } \\
\text {-Keandalan \& } \\
\text { Kelengkapan }\end{array}$ & $\sqrt{ }$ & $\begin{array}{l}\text { Basis Penyusunan } \\
\text { dan Penyajian }\end{array}$ & $\sqrt{ }$ \\
\hline 3 & $\begin{array}{l}\text { Sekapur Sirih, Tematik } \\
\text { Ringkasan Kerja, dan Ikhtisar } \\
\text { Utama }\end{array}$ & - & - & Kinerja & $\sqrt{ }$ \\
\hline 4 & $\begin{array}{l}\text { Laporan Pengurus } \\
\text { Perusahaan }\end{array}$ & $\begin{array}{l}\text { Fokus Strategi } \\
\text { dan Orientasi } \\
\text { Masa Depan }\end{array}$ & $\sqrt{ }$ & $\begin{array}{l}\text { Pandangan Masa } \\
\text { Depan }\end{array}$ & $\sqrt{ }$ \\
\hline 5 & Profil PT Timah & $\begin{array}{l}\text { Konektivitas } \\
\text { Informasi }\end{array}$ & $\sqrt{ }$ & - & - \\
\hline 6 & Risiko, Peluang dan Strategi & $\begin{array}{l}\text { Fokus Strategi } \\
\text { dan Orientasi } \\
\text { Masa Depan }\end{array}$ & $\sqrt{ }$ & $\begin{array}{l}\text {-Model Bisnis } \\
\text {-Risiko dan Peluang }\end{array}$ & $\sqrt{ }$ \\
\hline 7 & Tinjauan Operasional & - & - & $\begin{array}{l}\text { Strategi dan Alokasi } \\
\text { Sumber Daya }\end{array}$ & $\sqrt{ }$ \\
\hline 8 & $\begin{array}{l}\text { Analisis dan Pembahasan } \\
\text { Manajemen }\end{array}$ & $\begin{array}{l}\text { Konektivitas } \\
\text { Informasi }\end{array}$ & $\sqrt{ }$ & - & - \\
\hline 9 & Tata Kelola & - & - & Tata Kelola & $\sqrt{ }$ \\
\hline 10 & $\begin{array}{l}\text { Tanggung Jawab Sosial } \\
\text { Perusahaan }\end{array}$ & $\begin{array}{l}\text { Hubungan } \\
\text { Dengan } \\
\text { Stakeholders }\end{array}$ & $\sqrt{ }$ & $\begin{array}{l}\text { Ikhtisar Organisasi } \\
\text { dan Lingkungan } \\
\text { Eksternal }\end{array}$ & $\sqrt{ }$ \\
\hline 11 & Informasi Bagi Investor & $\begin{array}{l}\text { Hubungan } \\
\text { Dengan } \\
\text { Stakeholders }\end{array}$ & $\sqrt{ }$ & - & - \\
\hline
\end{tabular}

Tidak terlalu jauh berbeda dengan tampilan sampul pada tahun sebelumnya, pada tahun 2015 perusahaan juga menampilkan sebuah pemandangan tampak dari sebuah tebing yang cukup tinggi disertai dengan sebuah pohon yang daunnya sudah berguguran sehingga hanya tersisa batang dan rantingnya saja. Pada tebing tersebut tampak seseorang yang sedang memanjat. Pada sampul tersebut juga tertulis "Optimalisasi Kekuatan untuk Menghadapi Tantangan Menuju Pertumbuhan Berkelanjutan”. Dari tampilan sampul dan tulisan yang tertulis mencerminkan bahwa perusahaan ingin mengoptimalkan kekuatan perusahaan di dalam menghadapi tantangan untuk menuju pertumbuhan yang berkelanjutan. 
Poin selanjutnya terkait dengan poin yang terdapat pada integrated annual report perusahaan. Poin ini berjudul "Tentang Laporan Ini”. Pada poin ini, pelaporan untuk setiap tahunnya tidak mengalami perbedaan yang signifikan, perusahaan membahas mengenai latar belakang pelaporan yang dibuat, standar pelaporan yang digunakan, periode dan frekuensi pelaporan, penetapan isi dan penggunaan laporan, lingkup dan batasan laporan. Selain itu juga tercantum bahwa perusahaan menggunakan prinsip materialitas yaitu prinsip yang sesuai dengan prinsip pada integrated report. Adanya standar laporan dan penetapan isi pada poin ini menunjukkan bahwa pelaporan yang dilakukan telah sesuai dengan elemen di dalam integrated report yaitu basis penyusunan dan penyajian, materialitas serta keandalan dan kelengkapan.

Selanjutnya pembahasan pada poin yang diberi judul "Sekapur Sirih, Tematik Ringkasan Kerja, dan Ikhtisar Utama". Penamaan yang dilakukan perusahaan pada setiap periode pelaporan memiliki perbedaan. Namun pembahasan yang dilakukan tetap sama. Pada bagian Sekapur Sirih, perusahaan memaparkan tentang aspek pengelolaan perusahaan dan aspek operasional. Sedangkan pada bagian ikhtisar utama, perusahaan memberikan informasi terkait dengan ikhtisar keuangan dan ikhtisar kinerja operasional perusahaan. Informasi tersebut disajikan dengan menggunakan tabel maupun grafik. Selain itu perusahaan juga mencantumkan informasi terkait peristiwa penting yang dialami perusahaan pada periode yang bersangkutan. Pengungkapan pada poin ini menunjukkan bahwa perusahaan mengungkapkan elemen-elemen sesuai yang diatur dalam IIRC yaitu elemen kinerja.

Pembahasan berikutnya yaitu poin terkait dengan laporan yang dilakukan oleh pihak perusahaan. Poin tersebut diberi judul "Laporan Pengurus Perusahaan". Setiap periode diberi judul yang berbeda namun dengan maksud yang sama. Pelaporan pada poin ini dilakukan oleh pihak perusahaan khususnya Dewan Komisaris dan Dewan Direksi. Pada tahun 2013, pelaporan penting disampaikan oleh dewan direksi terkait total pendapatan usaha perusahaan yang mencapai hampir Rp5,9 miliar, turun 20\% dari tahun 2012.

Pada tahun berikutnya total pendapatan dilaporkan mencapai $\mathrm{Rp} 7,4$ triliun dan kenaikan laba bersih sebesar Rp638 miliar. Sedangkan pada tahun 2015, total pendapatan menurun $8,6 \%$ dari tahun sebelumnya, sehingga laba bersih mengalami penurunan sebesar Rp101,56 miliar.

Selain itu, pelaporan juga memberikan informasi terkait kinerja dan prospek, rencana bisnis, dan strategi untuk setiap tahun berikutnya. Sesuai dengan pembahasan ini, maka dapat dilihat bahwa pengungkapan tersebut sesuai dengan elemen dan prinsip pada integrated reporting yaitu pandangan masa depan serta fokus strategi dan orientasi.

Pembahasan poin selanjutnya yaitu poin "Tentang PT Timah" atau "Profil PT Timah". Pada poin ini, perusahaan memaparkan informasi terkait dengan perusahaan itu sendiri, seperti alamat, sejarah, visi dan misi, tujuan, struktur organisasi bidang usaha, 
serta produk dan layanan. Selain itu, informasi terkait komposisi pemegang saham dan profil para pejabat perusahaan juga disajikan. Informasi yang disajikan menggunakan teks naratif maupun tabel. Pelaporan poin ini menunjukkan bahwa perusahaan telah menerapkan prinsip-prinsip integrated report yaitu konektivitas informasi. Hal ini ditunjukkan adanya konektivitas informasi yang disampaikan oleh perusahaan pada poin Sekapur Sirih, Tematik Ringkasan Kerja, dan Ikhtisar Utama dengan informasi yang tercantum pada poin ini yang menyatakan bahwa 65\% dimiliki oleh Pemerintah Republik Indonesia dan $35 \%$ dimiliki oleh publik.

Selanjutnya pembahasan pada poin mengenai "Risiko, Peluang dan Strategi". Sama seperti pembahasan pada poin sebelumnya, pemberian judul pada poin ini terdapat perbedaan pada setiap periodenya, namun pembahasan yang dilakukan tidak jauh berbeda. Untuk poin ini, perusahaan berusaha untuk mendeskripsikan kegiatan operasional dan pencapaian finansial PT Timah pada tahun tersebut, serta prospek dan strategi tahun berikutnya. Perusahaan menyajikan sasaran perusahaan jangka panjang pada lima tahun mendatang yakni pertumbuhan profit minimal $15 \%$ pertahun. Perusahaan juga menjelaskan tentang kebijakan manajemen resiko keuangan yang termasuk resiko pasar, resiko kredit, dan resiko likuiditas.

Masih sama seperti pada tahun sebelumnya, perusahaan sadar akan pentingnya pengelolaan resiko, hal tersebut diperkuat dengan pernyataan pada integrated report tahun 2015 halaman 112:

PT Timah (Persero) Tbk memahami bahwa upaya pengendalian risiko
merupakan bagian dari upaya penerapan tata kelola yang baik, sehingga
setiap perubahan-perubahan internal dan eksternal yang menghasilkan
ketidakpastian tersebut dapat diidentifikasi, dipantau dan dimitigasi agar
dapat menopang PT Timah (Persero) Tbk dalam mencapai tujuan tujuan
dan sasaran perseroan dalam menciptakan nilai tambahdalam setiapaktivitas bisnisnya.

Menariknya, pada poin ini perusahaan menyajikan informasi mengenai model bisnis perusahaan tersebut. Model bisnis ini merupakan sebuah cerita ringkas bagaimana seharusnya perusahaan sebagai sebuah perusahaan yang memiliki tujuan utama menghasilkan profit, namun pada saat bersamaan banyak manfaat yang secara langsung ataupun tidak langsung bagi entitas yang berhubungan dengannya. Dari seluruh pembahasan pada poin ini dapat dilihat bahwa perusahaan melaporkan sesuai dengan elemen-ekemen di dalam integrated reporting yaitu fokus strategi dan orientasi masa depan, risiko dan peluang, serta model bisnis.

Pada poin berikutnya membahas tentang "Tinjauan Operasional". Judul pada poin ini untuk setiap periodenya berbeda seperti pada pembahasan sebelumnya. Pembahasan yang dilakukan pada tahun 2013 adalah mengenai profil tenaga kerja, kebijakan, komitmen, serta penerapan praktik ketenagakerjaan di perusahaan tersebut. Perusahaan banyak menggunakan tabel, gambar, maupun grafik untuk menjelaskan tentang jumlah, kelompok, dan komposisi karyawan-karyawannya. Untuk mengembangkan karyawannya, perusahaan memiliki sebuah program pengembangan 
tenaga kerja dengan memperhatikan tiga aspek, yaitu aspek pengetahuan, keterampilan, dan sikap disertai kerja diselaraskan dengan kompetensi inti, rencana strategis, dan pencapaian rencana kerja jangka pendek dan jangka panjang termasuk mempertimbangkan adanya perubahan teknologi/keterampilan baru.

Pada tahun 2014, pembahasan menekankan pada peningkatan intensitas program efisiensi untuk memastikan terkendalinya biaya produksi dan naiknya profitabilitas operasional. Selain itu, perusahaan juga membahas strategi pengembangan usaha perusahaan yakni dengan berbagai cara seperti merger, dan penggabungan dua anak perusahaan. Perusahaan juga merealisasikan program pelatihan dan pengembangan kompentensi yang terbuka bagi setiap karyawan.

Masih sama seperti pada tahun sebelumnya, pada tahun 2015 perusahaan juga masih tetap memandang bahwa Sumber Daya Manusia (SDM) merupakan aset penting bagi kesuksesan kegiatan usaha dan operasional perusahaan sehingga perusahaan melakukan pengelolaan dan pengembangan terhadap SDM. Strategi pengelolaan dan pengembangan SDM perusahaan disusun dan dituangkan dalam roadmap yang terbagi kedalam tiga horizon besar dalam membangun pilar pengembangan bisnis perusahaan. Tidak hanya terkait strategi pengelolaan dan pengembangan SDM, informasi tentang jumlah karyawan juga disajikan dengan jelas menggunakan tabel. Perusahaan juga berupaya menumbuhkembangkan budaya sadar akan risiko insiden kecelakaan kerja pada seluruh jajaran, sehingga perusahaan menyusun dan mengimplementasikan roadmap Budaya K3. Pentingnya K3 membuat perusahaan mengadakan pelatihan penanggulangan insiden kecelakaan kerja serta membentuk Komite K3 yaitu Panitia Pembina Keselamatan dan Kesehatan Kerja (P2K3) yang struktur atau susunan panitianya dijabarkan dengan menggunakan tabel. Dari pembahasan tersebut dapat dilihat bahwa pembahasan pada poin ini menerapkan elemen pada integrated report yaitu strategi dan alokasi sumber daya.

Pembahasan berikutnya mengenai poin "Analisis dan Pembahasan Manajemen". Untuk tahun 2013, perusahaan tidak mencantumkan poin ini. Sedangkan pada tahun 2014, pembahasan sub poin Tinjauan Umum tentang perusahaan yang berusaha untuk memastikan kesiapan perusahaan menyambut peluang sekaligus tantangan untuk menjadi pemain sektor industri pertimahan skala global. Pada sub poin Tinjauan Bisnis dijelaskan bahwa sebagian besar segmen bisnis perusahaan hingga akhir tahun 2014 berkaitan dengan usaha di bidang pertimahan. Selanjutnya pada poin Tinjauan Keuangan, secara umum perusahaan memaparkan bahwa seiring dengan naiknya pendapatan, perusahaan meningkatkan jumlah distribusi nilai perolehan ekonomi. Pada tahun 2014, jumlah pendapatan usaha perusahaan sebesar Rp7.371,20 miliar.

Pada tahun 2015, perekonomian global yang lesu mengakibatkan harga komoditas timah menjadi anjlok. Harga rata-rata timah di tahun 2015 adalah 16.313 dollar AS lebih rendah dari harga rata-rata timah tahun 2014 yang mencapai 21.686 dollar AS per metrik ton. Hal ini dijelaskan dengan menggunakan teks naratif sedangkan 
pergerakan harga timah selama tahun 2015 dicantumkan dengan menggunakan tabel dan grafik. Perusahaan juga membahas seputar segmen bisnis yang dilaksanakan beserta dengan kinerjanya yang dipaparkan dengan jelas menggunakan teks naratif. Sub poin utama Tinjauan Keuangan juga kembali membahas mengenai laba bersih yang diperoleh oleh perusahaan yaitu sebesar Rp101,6 miliar, hal ini dilaporkan dengan teks naratif. Pembahasan pada poin ini menunjukkan bahwa adanya konektivitas informasi perusahaan sesuai dengan yang diatur dalam IIRC.

"Tata Kelola Untuk Pertumbuhan Berkelanjutan" merupakan poin pembahasan selanjutnya. Pada tahun 2013, perusahaan memaparkan tentang struktur, kebijakan, dan praktik tata kelola perusahaan, serta perwujudan kepatuhan PT Timah untuk menjamin usaha berkelanjutan. Perusahaan memaparkan implementasi tata kelola perusahaannya melalui teks naratif yang dilengkapi dengan bagan prinsip utama dalam tata kelola. Poin ini juga disertai dengan amanat, independensi, komposisi, serta pelatihan dan peningkatan profesionalisme dewan direksi dan dewan komisaris, dan komite audit. Pada poin ini, pembahasan mengenai manajemen resiko dan faktor resiko dikatakan penting oleh perusahaan, sehingga pada setiap sub poin pembahasan resiko terdapat pembahasan mengenai bagaimana cara mengelola maupun mengurangi resiko-resiko tersebut. Pada poin tata kelola ini juga berisi pedoman perilaku dan kepatuhan yang merupakan sebuah dasar penerapan perilaku yang mengatur hubungan-hubungan antara setiap pemangku kepentingan. Agar praktik tata kelola perusahaan berjalan dengan baik perusahaan mengadakan sosialisasi dan membentuk tim komisi khusus untuk pelaksanaan tata kelola perusahaan yang baik.

Pada tahun 2014, pembahasan menekankan pada upaya perusahaan di dalam peningkatan kualitas penerapan praktek terbaik Good Corporate Governance (GCG) bukan hanya untuk mematuhi peraturan perundang-undangan yang berlaku semata, namun juga sebagai upaya melakukan inovasi dan penyempurnaan pengelolaan secara berkelanjutan guna meningkatkan kualitas penerapan prinsip-prinsip GCG. Tidak hanya mengenai prosedur maupun pedoman perusahaan, pada poin ini juga perusahaan melaporkan informasi terkait keputusan dan tindak lanjut hasil dari Rapat Umum Pemegang Saham (RUPS). Informasi-informasi terkait komite-komite komisaris juga disajikan pada poin ini. Perusahaan juga menerapkan Sistem Pengendalian Internal (SPI). Terkait dengan resiko, perusahaan juga menyajikan informasi mengenai sistem manajemen resiko perusahaan dan evaluasi terhadap pelaksanaannya.

Pembahasan pada tahun 2015 tidak mengalami terlalu banyak perbedaan dengan pembahasan pada tahun sebelumnya. Terkait penerapan GCG, perusahaan berhasil mendapatkan kategori SANGAT BAIK dengan nilai 85,11 pada hasil penilaian yang dilakukan RSM Indonesia pada tahun 2015 untuk periode penilaian tahun 2014. Seperti pada tahun sebelumnya, pada tahun ini perusahaan juga kembali menyajikan informasi terkait struktur tata kelola perusahaan melalui sebuah bagan. Pembahasan mengenai sistem pengendalian internal perusahaan yang mengacu pada kerangka yang diakui 
secara internasional juga kembali dibahas. Perusahaan juga kembali menyajikan informasi terkait manajamen resiko, mulai dari prinsip-prinsip yang dianut, kerangka kerja, serta proses yang ditetapkan pada standar internasional dicantumkan oleh perusahaan pada sebuah tabel dengan disertai penjelasan menggunakan teks naratif.

Pada dasarnya, melalui poin ini perusahaan ingin menyatakan bahwa penerapan tata kelola yang dilakukan terus mengalami peningkatan dan dapat dimaknai adanya komitmen keberlanjutan dari Dewan Komisaris dan Direksi dalam membenahi sistem tata kelola perusahaan. Poin ini mengungkapkan elemen Tata Kelola yang diatur oleh IIRC.

Selanjutnya pembahasan pada poin mengenai "Tanggung Jawab Sosial Perusahaan". Untuk tahun 2013, pembahasan difokuskan pada strategi, inisiatif, dan praktik kebijakan kepedulian perusahaan terhadap pelestarian lingkungan dan pengembangan sosial. PT Timah juga membahas mengenai jumlah penggunaan serta pengelolaan material yang digunakan dalam bentuk tabel dilengkapi dengan teks naratif dan gambar. Pada poin ini perusahaan juga menyatakan bahwa selama tahun 2013, kegiatan perusahaan tidak ada satupun yang berlangsung di hutan lindung ataupun di hutan konservasi. PT Timah juga mendukung program pemerintah dalam pengendalian dan pengelolaan limbah khususnya dalam mereduksi emisi gas rumah kaca yang upayanya dijabarkan melalui teks naratif dan tabel dalam poin ini. Tidak hanya mengenai lingkungan, perusahaan juga memiliki sebuah program pemberdayaan masyarakat karena PT Timah menghargai pentingnya upaya untuk meningkatkan kesejahteraan masyarakat dimana perusahaan menjalankan operasinya berdasarkan landasan Visi dan Misi CSR PT Timah. Untuk meningkatkan kesejahteraan masyarakat lokal, salah satu program yang dimiliki oleh PT Timah adalah program bina lingkungan yang mencakup bidang pendidikan, pelatihan dan magang, pertanian, peternakan dan perikanan, penghijauan, serta pengolahan limbah.

Pada tahun 2014, perusahaan berupaya memenuhi harapan seluruh pemangku kepentingan melalui penyelenggaraan berbagai kegiatan operasional dimana sasaran akhirnya adalah terpenuhinya harapan mereka dengan menggunakan seluruh sumber daya yang tersedia secara maksimal. PT Timah menerapkan pola penambangan yang ramah lingkungan, mematuhi seluruh ketentuan perundang-undangan dibidang lingkungan dan melaksanakan berbagai program pengelolaan dan pemantauan lingkungan. Program-program tanggung jawab sosial perusahaan khususnya untuk melestarikan lingkungan tidak berbeda jauh dengan program pada tahun sebelumnya. Perusahaan masih tetap melakukan reklamasi, rehabilitasi lingkungan laut, pengendalian emisi pada gas rumah kaca, menggunakan beberapa material daur ulang dalam proses peleburan, dan pengelolaan limbah. Bagan juga digunakan oleh perusahaan untuk menggambarkan pengelolaan limbah cair yang diterapkan oleh perusahaan. Dengan menggunakan teks naratif, perusahaan melaporkan jumlah dana yang telah dikeluarkan untuk pengelolaan dan pemantauan lingkungan pada tahun 2014, yaitu sebesar Rp5,03 
miliar. Selain tanggung jawab terhadap pada pekerjanya, perusahaan juga tanggung jawab terhadap komunitas dengan melibatkan partisipasi dari masyarakat sekitar agar kehadiran perusahaan dapat meningkatkan taraf hidup dan kesejahteraan mereka. Pada tahun 2014 ini, perusahaan juga melanjutkan kembali beberapa kegiatan seperti Program Kemitraan, Bina Lingkungan, dan Corporate Social Responsibility (CSR).

Tahun 2015, pada poin ini menjelaskan bahwa perusahaan mengutamakan upaya pelestarian lingkungan yang didasari atas kesadaran akan tanggung jawab. Perusahaan juga melakukan tindakan pengawasan dan pencegahan serta senantiasa berupaya mengurangi dampak negatif dan pada saat yang bersamaan menciptakan sumbangsih positif melalui penciptaan nilai tambah terhadap lingkungan. Perusahaan juga menyajikan informasi terkait dampak dan risiko lingkungan dari kegiatan operasional yang mungkin akan timbul sehingga dapat membantu perusahaan untuk mengelola setiap aktivitas untuk mengurangi eksternalitas negatif yang berpotensi terjadi bagi lingkungan. Perusahaan juga mencantumkan informasi mengenai jumlah dana yang dikeluarkan untuk pengelolaan dan pemantauan lingkungan pada tahun 2015, yakni sebesar Rp2,8 miliar. Biaya ini menurun dari tahun lalu dikarenakan hasil program efisiensi dan terdapat beberapa pengeluaran yang tidak lagi dibebankan pada tahun 2015. Rincian pengeluaran tersebut disajikan oleh perusahaan dengan menggunakan tabel. Untuk membangun hubungan yang harmonis dengan masyarakat, perusahaan melakukan sumbangsih dengan menggunakan konsep investasi sosial, dimana kontribusi finansial dan non-finansial perusahaan yang awalnya bersifat sukarela diakumulasikan secara terencana dan terukur untuk memberikan prioritas pembangunan bagi masyarakat. Seperti pada tahun-tahun sebelunya, untuk meningkatkan kualitas hidup masyarakat secara berkelanjutan serta membangun hubungan yang harmonis dengan tokoh masyarakat dan instansi pemerintah disekitar wilayah operasi, perusahaan bekerja sama dengan instansi setempat melalui program Corporate Social Responsibility (CSR) dan Program Bina Lingkungan (PKBL).

Melalui poin ini dapat dilihat bahwa perusahaan melakukan tanggung jawab sosial untuk memenuhi harapan seluruh pemangku kepentingan sehingga sesuai dengan prinsip pada integrated reporting yaitu hubungan dengan stakeholder serta sesuai dengan elemen ikhtisar organisasi dan lingkungan eksternal.

Poin terakhir yang akan dibahas yaitu terkait dengan "Informasi Bagi Investor" dan "Pelibatan Pemangku Kepentingan". Pada tahun 2013, tercantum informasi mengenai Kebijakan Dividen dan Pembagian Dividen Perusahaan. Perusahaan menyatakan bahwa kebijakan dividen perusahaan adalah menetapkan dividen atas laba yang dihasilkan yang merupakan hak pemegang saham. Hal ini dituangkan dalam teks naratif. Selain itu, perusahaan juga menggunakan tabel untuk menjelaskan dengan lebih rinci mengenai pembagian dividen.

Pada tahun 2014, perusahaan menyajikan informasi mengenai ikhtisar saham yakni terkait dengan kinerja saham itu sendiri seperti harga saham maupun posisinya 
dengan menggunakan grafik serta tabel. Modal saham perusahaan yang 65\% saham biasa dan satu saham seri A dimiliki oleh Pemerintah Republik Indonesia dan sisanya dimiliki oleh masyarakat juga dipaparkan dengan jelas pada sebuah tabel. Penyajian dengan menggunakan tabel juga dilakukan pada penyampaian informasi tentang komposisi pemegang saham yang terbagi menjadi tiga kelompok, yaitu pemodal nasional, pemodal asing dan pemerintah Indonesia. Selain itu perusahaan juga menyertakan informasi daftar 10 besar pemilik saham publik terbesar dengan menggunakan tabel. Kepemilikan saham anggota dewan komisaris dan direksi juga disajikan dengan jelas pada sebuah tabel. Melalui teks naratif perusahaan menjelaskan tentang kebijakan dividen.

Sedangkan pada tahun 2015, Perusahaan menyadari bahwa pemangku kepentingan sangat penting untuk keberlanjutan perusahaan. Hal ini diperkuat dengan pernyataan berikut yang terdapat pada integrated report tahun 2015 halaman 140:

Perseroan memahami bahwa pemangku kepentingan memiliki peran dan fungsi yang sangat signifikan dalam keberlanjutan suatu perseroan

Penjabaran pendekatan yang dilakukan oleh perusahaan dalam mengelola hubungan dengan para pemangku kepentingannya disajikan dengan lengkap menggunakan teks naratif. Sedangkan informasi tentang pelibatan Pemangku Kepentingan selama tahun 2015, baik mengenai basis penetapan, metode pelibatan, tujuan, frekuensi, serta topik yang dibahas ditampilkan dengan jelas melalui sebuah tabel. Adanya poin ini serta informasi yang terdapat di dalamnya menunjukkan bahwa perusahaan melakukan pelaporan sesuai dengan prinsip integrated reporting yaitu hubungan dengan stakeholders.

Dari semua pembahasan yang sudah dipaparkan dalam poin Aspek Semantik dan Sintaktik dalam Integrated Reporting PT Timah menunjukkan bahwa pada dasarnya semua pelaporan yang dilakukan oleh perusahaan telah sesuai dengan prinsip-prinsip dan elemen-elemen yang dibutuhkan dalam menyusun integrated report.

\subsection{Aspek Pragmatik Dalam Integrated Reporting PT Timah}

Teori pragmatik merupakan teori yang pembahasannya terfokus pada pengaruh dari informasi terhadap perubahan dari perilaku para pemakai laporan. Akuntan, pelaku pasar modal, manajer, dan auditor merupakan contoh para pemakai informasi yang dapat diukur perubahan perilakunya. Adapun hal yang menjadi indikator terhadap perubahan perilaku para pemakai informasi antara lain perubahan harga saham, voluma saham, kinerja manajer, kinerja karyawan, kinerja perusahaan, dan perbedaan pemilihan metoda akuntansi. Atau dengan kata lain, teori ini membahas reaksi dari pihak yang dituju oleh informasi akuntansi. 
Tabel 4.2 Lokasi Aspek Pragmatik Pada Integrated Reporting

\begin{tabular}{clccc}
\hline \multicolumn{5}{c}{ Aspek Semiotika } \\
\hline No & Indikator Aspek Pragmatik & 2013 & 2014 & 2015 \\
\hline 1 & $\begin{array}{l}\text { Kinerja Perusahaan } \\
\text { (Penghargaan) }\end{array}$ & $\sqrt{ }$ & $\sqrt{ }$ & - \\
2 & $\begin{array}{l}\text { Perbedaan Pemilihan Metoda } \\
\text { Akuntansi }\end{array}$ & - & $\sqrt{ }$ & \\
\hline
\end{tabular}

Pada tahun 2013 aspek pragmatik ditunjukkan dengan adanya banyak penghargaan yang diperoleh oleh PT Timah. Adapun penghargaan yang diperoleh adalah penghargaan Indeks SRI Kehati, Website BUMN Terbaik, Website BUMN Pilihan Pembaca Sektor Energi, Pertambangan dan Sumber Daya Alam, Social Business Innovation 2013, BUMN Marketing Award 2013, Trusted Company-Good Corporate Governance Award, Best CSR Disclosure in Annual Report 2012, Best CSR Disclosure in Website 2013, dan Pratama-Pengelolaan Keselamatan Pertambangan yang secara berurutan diperoleh dari Yayasan SRI Kehati, Berita Satu, Warta Ekonomi, BUMN Track, Indonesian Institute for Corporate Governance, National Center for Sustainability Reporting, serta Kementrian Energi dan Sumber Daya Mineral. Selain semua penghargaan diatas, kepedulian perusahaan pada tahun 2013 di dalam menjaga dan memperbaiki kualitas lingkungan hidup dimana perusahaan berada telah mendapatkan sejumlah pengakuan dari pihak eksternal. Perusahaan mendapatkan penghargaan Proper Biru dari Kementrian Lingkungan Hidup Republik Indonesia.

Aspek pragmatik pada tahun 2014 ditunjukkan dengan adanya perbedaan pemilihan metode akuntansi. Perubahan ini dilakukan karena perusahaan telah menyesuaikan dengan prinsip akuntansi dan keadaan yang sesuai. Hal tersebut dapat dilihat pada integrated report tahun 2014 halaman 170:

Perseroan telah melakukan penelaahan kembali penafsiran terhadap fakta-fakta, keadaan serta prinsip akuntansi yang sesuai, dan memutuskan untuk merubah metode pengukuran properti investasi dari model biaya menjadi model nilai wajar.

Hal ini menunjukkan bahwa adanya kebermanfaatan informasi dari tahun 2013 yang menyebabkan PT Timah melakukan perbedaan pemilihan metoda akuntansi. Perubahan metode pengukuran properti investasi dari model biaya menjadi model nilai wajar menyebabkan perusahaan harus melakukan penyajian kembali laporan keuangan konsolidasian pada tanggal dan untuk tahun yang berakhir 31 Desember 2013. Hasilnya terjadi peningkatan pada laba tahun berjalan. Selain itu, aspek pragmatik lain yang dapat dilihat di tahun 2014 adalah tentang penghargaan yang diperoleh oleh perusahaan.

Sama seperti pada tahun-tahun sebelumnya, pada tahun 2015 aspek pragmatik juga dapat dilihat dari penghargaan yang diperoleh oleh perusahaan. Pembahasan pada poin Aspek Pragmatik Dalam Integrated Reporting PT Timah menunjukkan bahwa hal yang menjadi indikator perubahan perilaku para pemakai informasi yang disajikan oleh 
perusahaan melalui integrated reportnya adalah adanya peningkatan kinerja perusahaan dan perbedaan pemilihan metode akuntansi. Kedua indikator tersebut menyebabkan perubahan perilaku dari para pemakai informasi yang diwujudkan dengan adanya perolehan berbagai penghargaan serta peningkatan laba tahun berjalan setelah dilakukan penyajian kembali atas perubahan metode pengukuran properti investasi.

\subsection{Retorika Dalam Integrated Report PT Timah}

Retorika merupakan bahasa yang dimaksudkan untuk meyakinkan atau mempengaruhi orang lain. Di dalam pelaporan yang dilakukan oleh perusahaan khususnya annual report yang telah terintegrasi dimana pelaporannya didominasi oleh teks naratif, penggunaan retorika di dalam penyusunannya merupakan hal yang wajar.

Tabel 4.3 Lokasi Aspek Retorika Pada Integrated Reporting

\begin{tabular}{clccc}
\hline \multicolumn{5}{c}{ Aspek Retorika } \\
\hline No & \multicolumn{1}{c}{$\begin{array}{c}\text { Poin Pembahasan pada } \\
\text { Integrated Report }\end{array}$} & 2013 & 2014 & 2015 \\
\hline 1 & $\begin{array}{l}\text { Laporan Pengurus } \\
\text { Perusahaan }\end{array}$ & $\sqrt{ }$ & $\sqrt{ }$ & $\sqrt{ }$ \\
2 & Profil PT Timah & $\sqrt{ }$ & $\sqrt{ }$ & $\sqrt{ }$ \\
3 & Tata Kelola & $\sqrt{ }$ & $\sqrt{ }$ & $\sqrt{ }$ \\
4 & Tanggung Jawab Sosial & $\sqrt{ }$ & $\sqrt{ }$ & $\sqrt{ }$ \\
& Perusahaan & & & \\
\hline
\end{tabular}

Di dalam integrated report PT Timah dari tahun 2013 hingga 2015 dapat ditemukan penggunaan retorika. Pada laporan Dewan Komisaris dan Direksi terdapat pernyataan yang menyatakan bahwa di dalam melaksanakan program-program perusahaan khususnya yang berkaitan dengan tanggung jawab sosial, program tersebut tidak hanya memberikan manfaat bagi para pemangku kepentingan melainkan juga melibatkan para pemangku kepentingan yang terkait. Berikut merupakan kutipan dari pernyataan Dewan Direksi pada integrated report tahun 2013 halaman 37:

Secara koheren dan berkesinambungan, perusahaan membangun program-program yang tidak hanya memberi manfaat jangka panjang bagi masyarakat dan lingkungan sekitar, tetapi juga melibatkan masyarakat dan para pemangku kepentingan lain yang terkait.

Hal yang sama juga diungkapkan pada laporan Dewan Direksi tahun 2014 dan 2015. Apa yang disajikan oleh PT Timah pada dasarnya merupakan cerita retorik untuk membentuk image perusahaan dan mempengaruhi para penerima informasi.

Tidak hanya pada laporan Dewan Komisaris dan Dewan Direksi, retorika juga dapat ditemukan pada Profil Perusahaan tahun 2013 hingga 2015 yang menyajikan informasi mengenai identitas singkat dari PT Timah, review operasional bisnis, 
perkembangan bisnis dan penghargaan serta sertifikasi. Aerts (1994) dalam Nugroho (2009) menyatakan tentang teori self-presentation yang berarti orang (termasuk manajemen) memberikan penjelasan atas tingkah laku mereka yang dibentuk baik secara sadar maupun tidak yang berguna untuk mempertahankan pernyataan mereka mengenai identitas sosial atau image yang positif. Di dalam integrated report PT Timah, tingkah laku tersebut dianalogikan dengan keempat informasi yang tersaji di dalam Profil Perusahaan. Hal tersebut dilakukan untuk mempertahankan image positif pada PT Timah.

Pada Laporan Tata Kelola Perusahaan juga terdapat retorika yang terkait dengan kesadaran perusahaan mengenai pentingnya komunikasi atau interaksi dan hubungan positif antara perusahaan dan para pemangku kepentingan sehingga perusahaan menerapkan berbagai mekanisme untuk membina hubungan baik. Berikut merupakan kutipan dari integrated report tahun 2014 halaman 244:

Perseroan memandang keberlanjutan usaha dalam jangka panjang sangat erat kaitannya dengan kemampuan manajemen beserta segenap jajarannya dalam berinteraksi dan menyelenggarakan hubungan positif yang memberi mutual benefit bagi para pemangku kepentingan sehingga dalam berinteraksi dan berkomunikasi dengan mereka, perseroan menempuh sejumlah metode.

Hal ini hampir sama dengan pengungkapan pada tahun 2013 dan 2015. Pernyataan ini dapat dikategorikan sebagai cerita retorik. Melalui pernyataan tersebut perusahaan berusaha untuk memperoleh legitimasi dari para stakeholders-nya.

Retorika juga dapat ditemui pada pelaporan Tanggung Jawab Sosial Perusahaan. Pada tahun 2013, perusahaan menyatakan bahwa kepeduliannya terhadap lingkungan mendapatkan pengakuan dari pihak eksternal yaitu dengan mengikutsertakan saham perusahaan sebagai komponen indeks SRI Kehati. Berikut kutipan dari integrated report tahun 2013 halaman 199:

Kepedulian PT Timah dalam menjaga dan memperbaiki kualitas lingkungan hidup dimana perusahaan berada telah mendapatkan sejumlah pengakuan dari pihak eksternal.

Hal ini dilakukan perusahaan untuk menunjukkan kepada investor maupun para pemangku kepentingan bahwa perusahaan telah menjalankan program lingkungan dengan kinerja baik. Hal ini juga tentu untuk memperkuat citra positif yang dibentuk oleh perusahaan.

Teks naratif yang bersifat retorik yang terdapat dalam Integrated report PT Timah merupakan usaha perusahaan untuk memperoleh pencitraan positif dan legitimasi dari para stakeholder. Penjelasan mengenai fakta dan realitas perusahaan diharapkan dapat mempengaruhi penilaian para penerima informasi (stakeholder) terhadap PT Timah.

Pembahasan pada poin Retorika Dalam Integrated Report PT Timah menunjukkan bahwa aspek retorika pada integrated report perusahaan banyak terdapat pada poin Laporan Dewan Komisaris dan Direksi, Profil Perusahaan, Laporan Tata 
Kelola Perusahaan, dan Laporan Tanggung Jawab Sosial. Tertuangnya cerita retorik pada poin tersebut pada dasarnya dilakukan oleh perusahaan untuk memperoleh image positif dari para stakeholders.

\section{KESIMPULAN}

Berdasarkan pembahasan yang telah dilakukan, dapat diambil kesimpulan bahwa penyusunan integrated report yang dilakukan oleh PT Timah merupakan aspek semantik dan sintaktik. Penyimbolan yang dilakukan oleh PT Timah dalam memberikan informasi mengenai kegiatan fisis perusahaan disimbolkan perusahaan melalui bentuk integrated reporting atau annual report yang telah terintegrasi. Aspek semantik dan sintaktik dalam integrated report PT Timah ditunjukkan dalam poin-poin pelaporan. Terdapat sembilan poin yang dilaporkan pada tahun 2013, 11 poin pelaporan pada tahun 2014, dan 12 poin pelaporan pada tahun 2015. Aspek pragmatik dapat dilihat pada penghargaanpenghargaan yang diterima oleh PT Timah. Penghargaan-penghargaan tersebut menunjukkan bahwa informasi yang disampaikan PT Timah melalui integrated report memberikan perubahan perilaku pada pemakainya baik positif maupun negatif sehingga para pemakai memberikan apresiasi melalui penghargaan-penghargaan tersebut. Dalam hal ini perubahan perilaku pemakai pada PT Timah memberikan dampak yang baik atau positif terhadap perusahaan. Dan pada dasarnya, pelaporan yang dilakukan oleh perusahaan telah sesuai dengan prinsip-prinsip dan elemen-elemen yang dibutuhkan dalam penyusunan integrated reporting.

Pengungkapan informasi dalam bentuk cerita retorik pada dasarnya dilakukan perusahaan untuk membentuk image positif bahwa PT Timah menjalankan kegiatan bisnisnya tetap memberikan perhatian pada sosial dan lingkungan serta para stakeholdernya. Hal ini dilakukan untuk mengendalikan stakeholders sebagai penerima dan pemakai informasi sehingga perusahaan dapat memperoleh legitimasi dari para stakeholdernya. Aspek retorika pada perusahaan banyak disajikan pada poin Laporan Dewan Komisaris dan Direksi, Profil Perusahaan, Laporan Tata Kelola Perusahaan, dan Laporan Tanggung Jawab Sosial.

Penelitian ini merupakan penelitian dengan kualitatif dimana peneliti itu sendirilah yang menjadi instrument atau alat penelitian sehingga terdapat beberapa keterbatasan dalam pembuatannya. Keterbatasan pertama yaitu terkait hasil penelitian karena objek penelitian hanya fokus pada satu perusahaan saja yaitu PT Timah sehingga hasil yang diperoleh tidak menggambarkan hasil yang sama apabila diterapkan pada perusahaan yang berbeda. Keterbatasan kedua, penelitian ini menganalisis penerapan integrated reporting pada annual report PT Timah secara semiotik dengan paradigma interpretif maka terdapat subjektivitas dari peneliti. 


\section{DAFTAR PUSTAKA}

Argandona, A. (2011). Stakeholder Theory and Value Creation. Working Paper No. WP922. Retrieved from www.iese.edu/research/pdfs/di-0922-e.pdf

Brennan, N. \& Gray, S. J. (2000). Rhetoric and Argument in Financial Reporting: disclosures in profit forecasts and takeover documents. ACCA Occasional Research Paper No.31. London: Certified Accountants Educational Trust. Retrieved from http://www2.accaglobal.com/pubs/general/activities/research/ research_archive/orp-031-001.pdf

Budiani, R. J. (2011). Narsisme dalam Pelaporan Keuangan: Analisis Semiotik atas Laporan Keuangan Perusahaan yang Mengalami Kerugian. (Skripsi yang tidak dipublikasikan), Universitas Diponegoro, Indonesia.

Camiciottoli, B. C. (2012). Oral Financial Reporting: A Rhetorical Analysis of Earnings Calls. (Unpublished Thesis), Universitas di Pisa, Italy.

Carter P. \& Jackson, N.. (2004). For the Sake of Argument: Towards an Understanding of Rhetoric as Process. Jurnal of Management Studies, 41(3), 469-491.

Chariri, A. (2010). Rhetorics in Financial Reporting: An Interpretive Case Study, Jurnal Akuntansi dan Keuangan, 12(2), 53-70.

Craig, R., Garrott, L. \& Amernic, J. (2001). A “Close Reading” Protocol to Identify Perception-Fashioning Rhetoric in Web Site Financial Reporting: The Case of Microsoft. Accounting and The Public Interest, 1(1), 1-16.

Fitriany, K. (2009). Retorika Dalam Pelaporan Keuangan: Analisis Narrative Text Dalam Annual Report Perusahaan yang Mengalami Kerugian. (Skripsi yang tidak dipublikasikan), Universitas Diponegoro, Indonesia.

Fontaine, C., Haarman, A \& Schmid, S. (2006). The Stakeholder Theory. Retrieved from http://www.martonomily.com/sites/default/files/attach/Stakeholders\%20theory. pdf

Harahap, S. S. (2008). Analisa Kritis atas Laporan Keuangan. Jakarta: PT. Raja Grafindo Persada.

Jupe, R. (2005). Disclosures in Corporate Environmental Reports: A Test of Legitimacy Theory. Working Paper No. 91, University of Kent Canterbury. Retrieved from https://kar.kent.ac.uk/id/eprint/24451

Kriyantono, R. (2007). Teknik Praktis Riset Komunikasi. Jakarta: Kencana.

Lim, S. M., Wilmshurt, T., \& Shimeld, S (2010). Blowing in the Wind: Legitimacy Theory, an Environmental Incident and Disclosure. In APIRA Conference Proceedings (pp. 1-33). Sydney, Australia: APIRA 2010. Retrieved from 
http://apira2010.econ.usyd.edu.au/conference_proceedings/APIRA-2010-306Wilmhurst-Legitimacy-theory-an-environmental-incident-and-disclosure.pdf

Littlejohn, S. W. (2009). Theories of Human Communication (Edisi 9). Jakarta: Salemba Humanika.

Martono. (2016). Evolusi dalam Pelaporan Keuangan Perusahaan: Analisis Semiotik atas Integrated Reporting PT Pertamina. (Skripsi yang tidak dipublikasikan), Universitas Tanjungpura, Indonesia.

Moleong, L. J. (2006). Metodologi Penelitian Kualitatif (Edisi Revisi). Bandung: PT Remaja Rosdakarya.

Nugroho, F. A. (2009). Retorika dalam Pelaporan Corporate Social Responsibility: Analisis Semiotik atas Sustainability Report PT Aneka Tambang Tbk. (Skripsi yang tidak dipublikasikan), Universitas Diponegoro, Indonesia.

Perelman, C. (1982). The Realm of Rhetoric. Kluback, Notre Dame: The University of Notre Dame Press.

Piliang, Y. A. (2004). Semiotika Teks: Sebuah Pendekatan Analisis Teks. Mediator, 5(2), 189-198.

Pradana, F. A. (2016). Kajian Semiotik Laporan Tahunan PT. Bank Rakyat Indonesia, Tbk Sebelum dan Setelah menjadi Pemenang dalam Annual Report Award. (Skripsi yang tidak dipublikasikan), Universitas Negeri Malang, Indonesia.

Sakina, D. A., Wahyuni, N. I., Mas'ud, I. (2014). Narsisme dalam Pelaporan Corporate Social Responsibility: Analisis Semiotik Atas Sustainability Reporting PT. Kaltim Prima Coal dan PT. Perkebunan Nusantara XIII (Persero). e-Journal Ekonomi Bisnis dan Akuntansi, 1(1), 32-41.

Satori, D \& Komariah, A. (2009). Metodologi Penelitian Kualitatif. Bandung: Alfabeta.

Munawir, S. (2004). Analisis Laporan Keuangan (Edisi 4). Yogyakarta: Liberty.

Sugiyono. (2010). Memahami Penelitian Kualitatif. Bandung: Alfabeta.

Suwardjono. (2005). Teori Akuntansi: Perekayasaan Pelaporan Keuangan (Edisi 3). Yogyakarta: BPFE.

The International Integrated Reporting Council (IIRC). (2013). The International Integrated Reporting Framework. Retrived from https://integratedreporting.org/ wp-content/uploads/2013/12/13-12-08-THE-INTERNATIONAL-IRFRAMEWORK-2-1.pdf

Utomo, S T. (2011). Rasisme dalam Pelaporan Akuntansi: Analisis atas Annual Report PT. Perusahaan Gas Negara, Tbk dan PT. Aneka Tambang, Tbk dalam Perspektif Teori Komunikasi Aksi Habermas. (Skripsi yang tidak dipublikasikan), Universitas Diponegoro, Indonesia. 
Widiyastuti, Y. (2012). Evolusi dalam Pelaporan Keuangan Perusahaan: Analisis Semiotik atas Integrated Reporting. (Skripsi yang tidak dipublikasikan), Universitas Diponegoro, Indonesia.

Young, J. J. (2003). Constructing, Persuading and Silencing: The Rhetoric of Accounting Standards. Accounting, Organizations and Society, 28(6), 621-638. 